\title{
Rehabitar la Montaña: strategies and processes for sustainable communities in the mountainous periphery of Medellín
}

\author{
Reabitar a Montanha: estratégias e processos para comunidades sustentáveis \\ na periferia montanhosa de Medellín
}

Joseph Claghorn ${ }^{[0]}$, Francesco Maria Orsini ${ }^{\left[{ }^{b]}\right.}$, Carlos Alejandro Echeverri Restrepo ${ }^{[b]}$, Christian Werthmann ${ }^{[a]}$

\begin{abstract}
[a] Leibniz University Hannover, Department of Landscape Architecture, Herrenhäuserstr, Hannover, Germany
[b] EAFIT University, Center for Urban and Environmental Studies, Medellín, Colombia
\end{abstract}

\begin{abstract}
Thousands of poor, marginal communities' residents die due to landslide events every year. The quick urbanization of mountainous areas, combined with an increased frequency of landslide events induced by heavy rains due to climate change, is leading to increased deaths year after year, and the problem will only get worse. Landscape Architects, trained to analyze and intervene in situations with complex natural and social territorial dynamics, are in position to make positive contributions to mitigating risks in such situations. A collaborative effort between a team of landscape architects from Germany and Urbanists in Medellín Colombia is carrying out a four-phased research and implementation proposal to anticipate and mitigate risk in low-income settlements on Medellín's urban periphery. They propose five pilot projects to test risk mitigation strategies through monitoring and early warning systems, drainage improvements, urban agriculture, slope forestation, and developing sites with the supplied services.
\end{abstract}

Keywords: Community engagement. Disaster risk-management. Landscape architecture. Non-formal urbanization. Landscape urbanism.

\section{Resumo}

Milhares de moradores de comunidades pobres e marginais morrem em eventos de deslizamento de terra a cada ano. A rápida urbanização das zonas montanhosas, combinada com um aumento da frequência de eventos de deslizamento de terra induzidas por fortes chuvas devido às alterações climáticas, está levando ao aumento de mortes ano após ano, e o problema só tende a piorar. Arquitetos paisagistas, treinados para analisar e intervir em situações com dinâmicas territoriais naturais e sociais complexas estão em posição de fazer contribuições positivas para a mitigação de riscos em tais situações. Um esforço de colaboração entre uma equipe de arquitetos paisagistas da Alemanha e urbanistas em Medellín, estão realizando uma proposta

JC is master of Landscape Architecture (MLA), Harvard University, e-mail: claghorn@ila.uni-hannover.de FMO is MSc Urban Management and Development, Institute of Housing and Urban Development Studies, Rotterdam, e-mail: fm.orsini@gmail.com

CAER is Advanaced Urbanism Studies, Escuela Técnica Superior de Arquitectura de Barcelona, e-mail: aecheve30@eafit.edu.co CW is Dipl.-Ing. Landscape Architecture, University of Kassel, Germany, e-mail: werthmann@ila.uni-hannover.de. 
de pesquisa e implementação de quatro fases para antecipar e mitigar riscos em assentamentos de baixa renda na periferia urbana de Medellín. Eles propõem cinco projetos piloto para testar estratégias de mitigação de riscos através de sistemas de alerta precoce e de monitorização, melhorias de drenagem, agricultura urbana, inclinação da arborização, e sites em desenvolvimento com os serviços prestados.

Palavras-chave: Envolvimento da comunidade. Gestão de riscos de desastres. Arquitetura paisagística. Urbanização non-formal. Paisagem urbana.

\section{Introduction}

During public forum hosted by Medellin's EAFIT University in 2013, numerous academics, political leaders, urban planners, and architects discussed the merits and challenges of a bold new project proposal for Medellin's urban periphery, a steep, landslide prone, and economically impoverished zone known as ladera. Curiously, the agenda did not included anyone from the affected communities, but after all the presentations had been made, for and against a new transit monorail couched in a broader project known as the Cinturon Verde (Green Belt), a young girl representing a small but vocal community organization made an impromptu presentation, perhaps the most compelling presentation of the evening. Challenging many of the fundamental proposals that would have changed or erased the only home she had ever known, and decrying a community engagement process that she and her group saw as more manipulative than participatory, she concluded her remarks with a phrase that silenced the room, saying that "while the city turned its back, the ladera took us in"1. After her remarks, the room broke into applause, and within months the Cinturon Verde project monorail component quietly shelved, at least for the next couple of years. This is not to say that the ladera's neighborhoods had no need for better planning, or for innovative approaches and proposals. In fact, the issues facing these communities were extremely complex, and at times a matter of life and death. Planners have always had to balance conflicting needs and interest, and while the range of considerations is vast, the recent years have seen an increased emphasis on recognizing the significant impact of community-based, non-formal, and bottom-up processes on urban growth and development. At the same time, increased awareness

\footnotetext{
${ }^{1}$ Meeting Minutes Mesa POT (August 2013). Verbal Quote from Eulalia Borja Bedoya, resident of Barrio María Cano Carmbolas. at Mesa Plan Ordanemiento Territorial: Retos y oportunidades del cinturón verde Metropolitano. Medellín.
}

on territory and landscape importance has led to a re-emphasis of environmental protection and restoration, landscape quality, and in many situations, disaster preparedness and recovery issues. All of these were at play in Medellin's complex periphery, and had to be considered by a civic administration actively exploring new approaches to reduce social and physical vulnerability in non-formal settlements (Figure 1).

It is in this context that an interdisciplinary team, co-directed by Alejandro Echeverri, head of EAFIT University's Center for Urban and Environmental Studies (Urbam) and a team directed by Christian Werthmann with the Leibniz University of Hannover, Germany, with funding support from the City of Medellin, embarked upon a multi-phased research project to find and test innovative, community-based strategies to address the risk and ecology pressing issues in these peripheral neighborhoods. Both Echeverri and Werthmann were committed to improving living conditions in disadvantaged neighborhoods, but were unsettled by the prospect that certain interventions might actually encourage occupation of dangerous sites, and that the need to grant neighborhoods security of tenure must be tempered by the prospect that granting security of tenure in fundamentally unsafe sites was an ethically untenable position. This article presents the conclusions of the first phase of their collaborative research, looking at the phenomena of landslide risk in the Medellin region, as well as of the second phase, which looked closely at the territorial and social processes dynamic in two specific neighborhoods. We also describes an intended third research phase to implement five small-scale pilot projects designed to test the technical and social implementation of promising strategies. The results of these three phases of research are intended to inform a fourth and final phase of research, to make planning recommendations that can better manage risk and environmental issues while taking into account these dynamic social and territorial processes (Figure 2). 


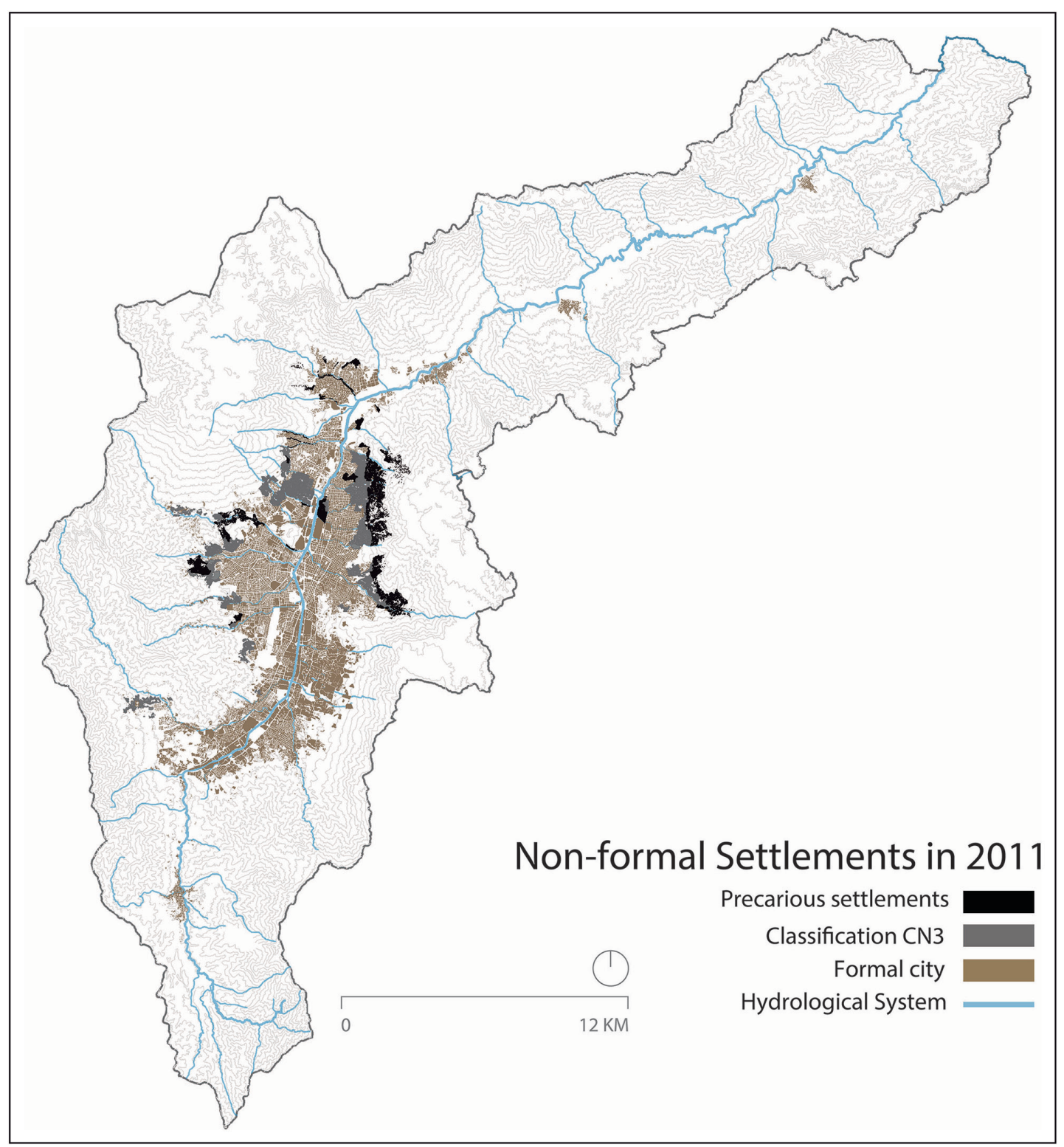

Figure 1 - About $8 \%$ of the population of the Aburra valley lives in precarious settlements Source: Echeverri et al. (2012).

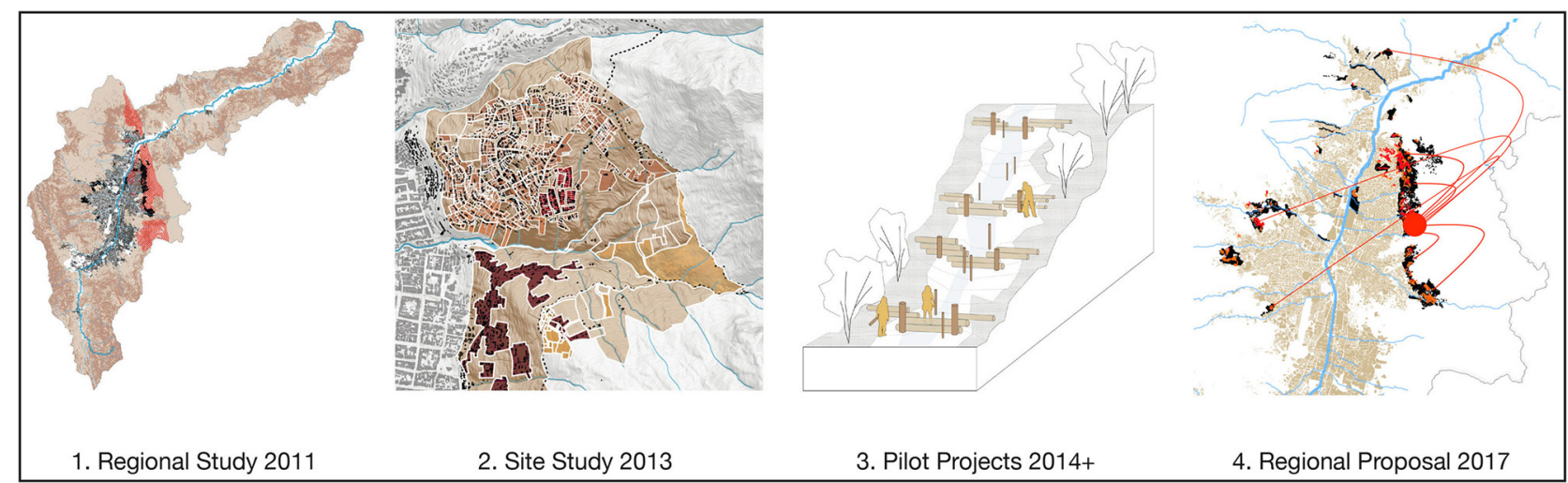

Figure 2 - Four phases of intended research plan

Source: authors from EAFIT University and Leibniz University. 


\section{Urban planning and design in Medellin - historical background}

To frame the issues at stake in these communities, it is helpful to briefly review some historical context of urban growth, design, and planning in Medellin. This history of planning got off to a rather illustrious start when the city hired the architect José Luis Sert and his business partner Paul Wiener to draft a plan for the urban area growth. After a brief visit to the valley, and a few months of work back in New York City, Sert issued the Plan Piloto. The 1949 Plan Piloto was in many ways ahead of its time and precedes by nearly half a century the intellectual developments that were to become known in the 1990s as Landscape Urbanism. The Plan Piloto's primary focus is not on Medellin's streets and roads, but on its topographical features. Most conspicuous on the Sert and Wiener map are dark colorings along its steep ravines known as quebradas, recommending that they are left un-built due to their challenging topography. The new neighborhood grids sketched in the Plan Piloto defer to the land shape. Another sensible recommendation was to establish a boundary for urban growth roughly corresponding to the ladera, where the surrounding mountains abruptly rise from the valley floor. Sert may or may not have been aware of the landslide risk in the ladera, but the ultimate message of his master plan is clear; future growth should defer to the valley's topographical structure (Schnitter, 1999).

Despite Sert's plan recommendations, Medellin's growth over the next 50 years would take a very different direction. The outbreak of Colombia's civil war and increasing violence in the countryside had created an unending stream of internal migrants and refugees looking for a new start in Colombia's industrial and commercial capital. With little to no resources, these new migrants would often build their housing in the only real estate available to them, precisely in lands that the Piloto Plan declared off-limits to development, such as the ladera or the precipitous quebradas bisecting the valley. In these settlements, residents were subjected to powerful forces of physical and social vulnerability. There, many became trapped in a downward spiral of poverty, crime, and more violence fueled by the world's most powerful drug cartel, based at that time in Medellin. The violence in these communities made effective governance by the already weakened civic institutions nearly impossible, and projects by the local public administration focused on the city's core areas, and on conventional infrastructures such as roads and highways. In contrast to Sert and Wiener's Plan Piloto, the 1985 Plan de desarrollo metropolitano del Valle de Aburra: para la consolidación de la metropolis (Municipality of Medellín, 1985) focused almost exclusively on transit infrastructure, with almost no regard for the city's topographical features, except for the preservation of a newly expanded Urban Growth Boundary along the city's edges. Apart from this, there was little regard by planners for conditions at the city's edges. It was only after Pablo Escobar's death, the cartel's leader, in late 1993 that the city was able to begin restoring its normal governance, and to deal with the seemingly insurmountable problems that were plaguing its peripheral neighborhoods.

During the mayoral term of Sergio Fajardo between 2003 and 2007, the city initiated the most visible interventions into the impoverished communities of Medellin's peripheries as part of the wider ranging Proyectos Urbanos Integrales. Mayor Fajardo believed that by prioritizing these communities for civic investment, the cycle of poverty, violence, and social vulnerability could be overcome. (Fajardo, 2007) Many of his term high-profile interventions focused on education, most notably visible in the numerous designer libraries and library parks constructed around the city. The construction of high-end design projects in and around neighborhoods that were considered undesirable slums was a bold move that challenged the perception that civic investment so far had disproportionately favored the city's upper classes. The most iconic interventions during this period were strategically located at the heart of the most vulnerable communities in order to enhance a process of social and physical inclusion with the formal city, with innovative transit infrastructures, most notably the cable cars system known as the Metrocable, designed to link hard to reach communities into the overall urban transit network, connecting communities that had so far been plagued by unemployment and crime. The upgrades of Fajardo's term were not just high profile projects for show; countless other less visible upgrades, such as the installation of simple stairways, handrails, drainage systems, and other necessary infrastructural improvements, probably had a more significant impact on the daily quality of life of many communities' residents, and engendered for the 
first time a level of trust in the poorest communities for civic institutions. Despite these upgrades success, one major challenge in the peripheral communities, of the landslide risk, was going largely unaddressed. This changed in 2010 when a devastating landslide in the working-class neighborhood of La Gabriela claimed at least 85 lives. The site of the devastation was less than 3 kilometers from the Metrocable and the famous Biblioteca España that at the time were appearing on countless architecture magazine covers, and caused even the most ardent supporters of these projects to question the need for alternative strategies.

\section{The issue of landslide risk - a regional picture}

Echeverri and Werthmann were among the upgrading program supporters who were deeply unsettled by the landslides. Echeverri, an architect and urban designer as well as director for urban strategic projects under the tenure of major Fajardo, had years of experience doing urban upgrading in similar precarious communities. Werthmann, trained as a landscape architect and then an Associate Professor at Harvard University, was researching the role of landscape architectural strategies in improving living conditions, mitigating environmental damage, and providing economic opportunity in non-formal settlements. Echeverri and Werthmann soon devised a research plan to look closely at the problem of non-formal occupation in hazardous sites, with the goal of finding new strategies to complement the set of urban upgrading strategies previously defined and implemented by civic leaders, to consolidate non-formal settlements in Medellin, with the goal of providing safer living conditions for already settled communities, and to anticipate and inhibit future non-formal growth in high-risk sites.

In the first phase of the research, the two teams identified and mapped risk patterns and major landslide events, and overlaid these with historical growth patterns and future projections of urban growth. The results were published in the report Shifting Ground (Echeverri et al., 2012) (Spanish: Rehabitar la ladera). The research reiterated that the disaster in La Gabriela was not an isolated event, but part of a larger pattern where at least 854 people have died in catastrophic landslides in Medellin's Aburra valley in the last 80 years. More surprisingly, however, the team identified that the four most devastating events, displacing thousands and claiming over 750 lives in total, all occurred on the valley's north-eastern slopes, close to the area that was the focus of many of Fajardo's most prominent interventions. These slopes were particular vulnerable to landslides due to their unique geological composition, with an underlying bedrock composed of structurally weak and highly erosive dunitic rock (Figure 3).

In addition to mapping risk, the research in Shifting Ground also focused on the logic of non-formal land occupation, and identified four primary factors that seemed to attract non-formal urban growth in Medellin. The first three of these were fairly intuitive: non-formal settlement activity would occur in proximity to existing roads, proximity to public utilities, and proximity to existing areas of settlement, especially other non-formal settlements. Since the eastern slopes are relatively close to the urban core of Medellin, and hence many jobs, growth pressure from these three factors is particularly high. The fourth factor is initially counterintuitive; settlers tended to build in areas protected from development, in the case of Medellin, in areas located outside of the Urban Growth Boundary. Ironically, the imposition of this urban growth boundary seemed to have had the opposite effect. Since conventional development could not take place here, the land became essentially worthless to its owners. The land became valuable then only to the large migrant population who were moving to the city to find opportunity and to escape escalating violence in the countryside. As the city grew, policy makers occasionally updated the official urban growth boundary to reflect the current reality, with the last update occurring in 1996, but this only seems to have moved the problem outward (Echeverri et al., 2012, p. 56-63). The research observed that since 1996, thousands of new houses have been built outside of the growth boundary and concluded that by 2030, an estimated 70,000 persons would settle in precarious sites around the valley, many in sites that are exposed to ever-higher geological risk, and much of this outside the updated growth boundary (Echeverri et al., 2012, p. 43).

Shifting Ground identified two further worrying trends in the calculation of landslide risk in Medellin's peripheries. An analysis of yearly rainfall in the Aburra valley compared with the total number of yearly landslide events shows a direct correlation between these numbers. This finding is corroborated 


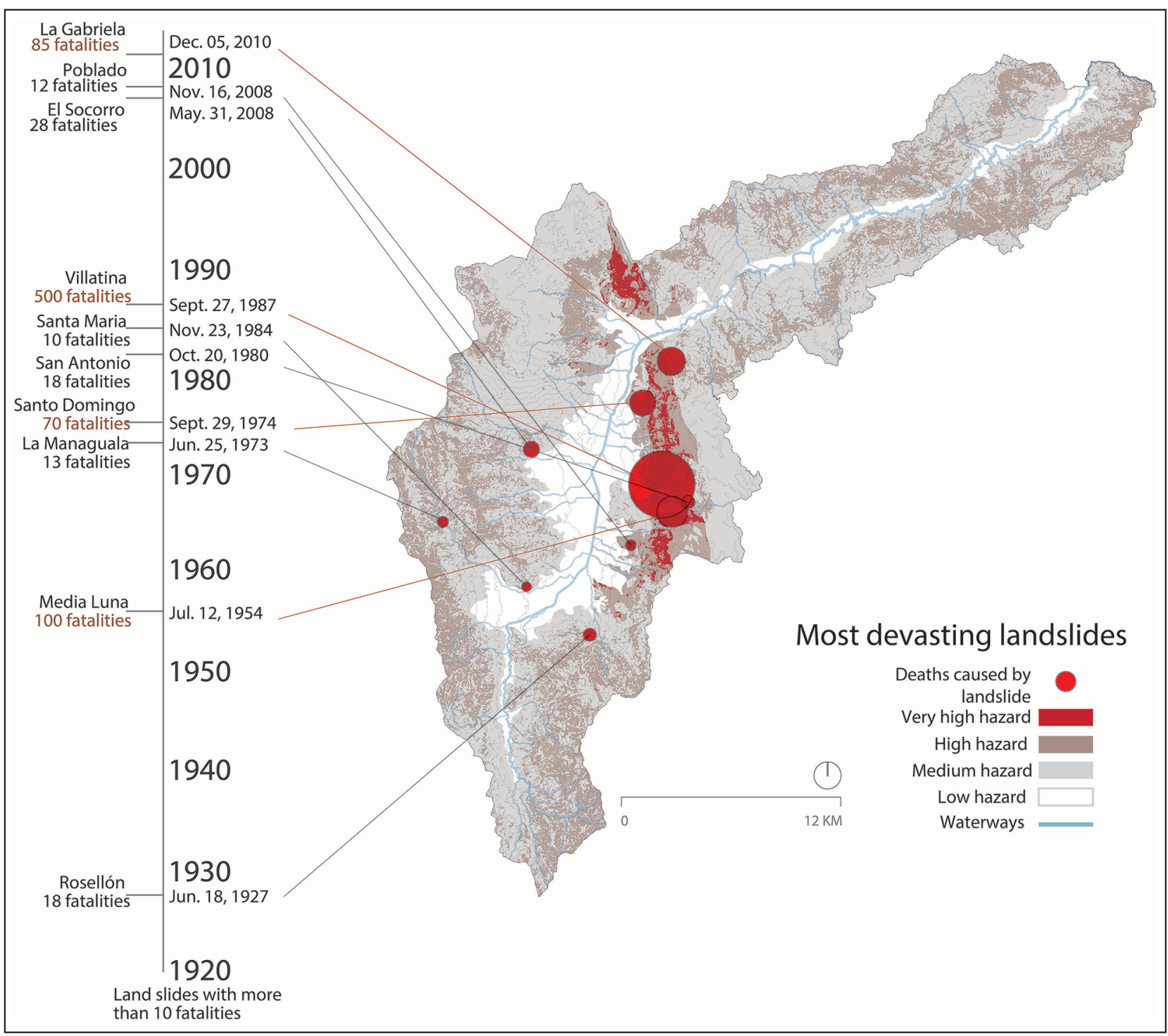

Figure 3 - The highest concentration of devastating landslides have occurred on the eastern valley slopes due to their dunitic soil composition Source: Echeverri et al. (2012).

by an analysis of landslide events in a global data set curated by Dr. David Petley at the University of Durham, where the dataset shows a sharp increase in landslides during local monsoon seasons between the years 2004 and 2010. The Durham dataset shows another worrying trend-an overall rising trend in landslide events. While the dataset sample time is too short to extrapolate a statistically significant conclusion, Petley hypothesizes that the global climate change with an increase of intense precipitation events could be responsible for this rising trend (Petley, 2012). If the trend towards more extreme weather events is also reflected in the Aburra valley, there will be more and more deadly incidents in the future. The second complicating factor identified in Shifting Ground is the impact of human interventions on landslide vulnerability. An analysis of the four worst landslides in the Aburra valley found that, in addition to the presence of natural risk factors, all four also had a strong human induced trigger associated with the disaster, such as the overflow and blockage of a drainage channel, or even the presence of a non-formal carwash, whose drainage saturated the soil. Indeed, direct human impacts on land, such as small-scale constructions, slope cuts, drainage alterations, deforestation, and overgrazing, can lead to an increased risk of incidents (Ojeda \& Donnelly, 2006). Thus, in addition to non-formal occupation exposing 
more and more people into harm's way, the act of occupation and construction itself, with its attendant alterations to the processes of the land, could also be increasing the risk and vulnerability.

\section{Recent policy initiatives: BIO-2030}

The severity of the disaster in La Gabriela, as well as the emerging understanding of the risk patterns documented in Shifting Ground made clear that addressing the unsustainable urban growth on the valley slopes should be a priority in the local urban planning agenda. In addition to their involvement with Shifting Ground, Echeverri's team at the time was also consulting on a new strategic plan for the metropolitan area of Medellin, called BIO2030, which was being developed with the goal of defining a vision for the city over the next twenty years. The territorial analysis in BIO2030 came to the same conclusions for many, as the Sert and Wiener plan of 1949, and focused on the major topographical structuring elements of the Aburra valley; the Medellin River, the quebradas, and the ladera. The plan recognized that, despite abundant infrastructure, much of the land around the Medellin river was underutilized post-industrial land, which if redeveloped could provide much needed open space as well as substantial amounts of land for the development of new housing, easing growth pressures in the booming city. Several projects along the stream corridors had also met with success, as testified by a significant stream corridor upgrade project in the small quebrada Juan Bobo which consolidated the community, provided safe housing, and turned the garbage choked stream into an amenity of public space (Salazar, 2011). The last of the three structuring elements, the ladera, presented the biggest challenges. While geological risk maps allowed for some occupation of the high slopes, Bio 2030 recommended largely curtailed future growth in this landscape due to the difficulty or impossibility associated with guaranteeing safe conditions free from risk, as well as the challenges associated with providing services and infrastructure in these remote and hard to access locations. Accordingly, as a mean to obviate further non-formal occupation of the slopes, Bio 2030 recommended the introduction of anticipatory actions to manage and control new growth, conscious that the frameworks imposed by regulatory plans without specific actions had proved to be ineffective in non-formal contexts in the past. The establishment of productive land uses such as farming and peri-urban parks in unsafe zones close to existing settlements, and zones of ecological protection and restoration with light tourism in others would be amongst anticipatory actions. Indeed all three areas of interest in the new city, river, quebradas, and ladera strategic visions, would be tied together through the overarching goal of ecological protection and restoration, which would serve as a catalyst to further the city's social (Municipality of Medellin, 2011) (Figure 4).

Following the Bio 2030 publication, the city moved forward to further develop the river and ladera's concepts. While technically challenging and certainly expensive, the river project fell into the realm of more conventional urban design, and an international competition in 2013 generated many compelling visions for the river. Financing could be generated as in many urban renewal projects through public-private partnerships with real estate investment interests. Interventions in the ladera, however, would prove more challenging. Unlike the lands surrounding the river, land where resettlement would happen on the dangerous slopes could not be feasibly redeveloped into a more economically productive land use. Without a definite land use, lands slated for resettlement would run the risk of being reoccupied in the future. A second concern was the extremely high cost of the resettlement program. When including mitigation works to limit the resettlement scope, this would cost the city an estimated USD $\$ 45,000$ per house (Municipality of Medellin, 2011; EDU, 2011). Extrapolating this cost to assume the resettlement and risk mitigation for all those in the city's area of risk, the total cost would be several times the yearly budget of the city of Medellin. Countless other questions arose; similar resettlement projects in the past had moved people far from supporting social networks and far from their jobs and for those who fell through the cracks, extreme poverty or crime were the only viable alternatives. Reducing the physical vulnerability of the residents of the ladera slightly, while significantly increasing their social vulnerability was a justifiable strategy? 


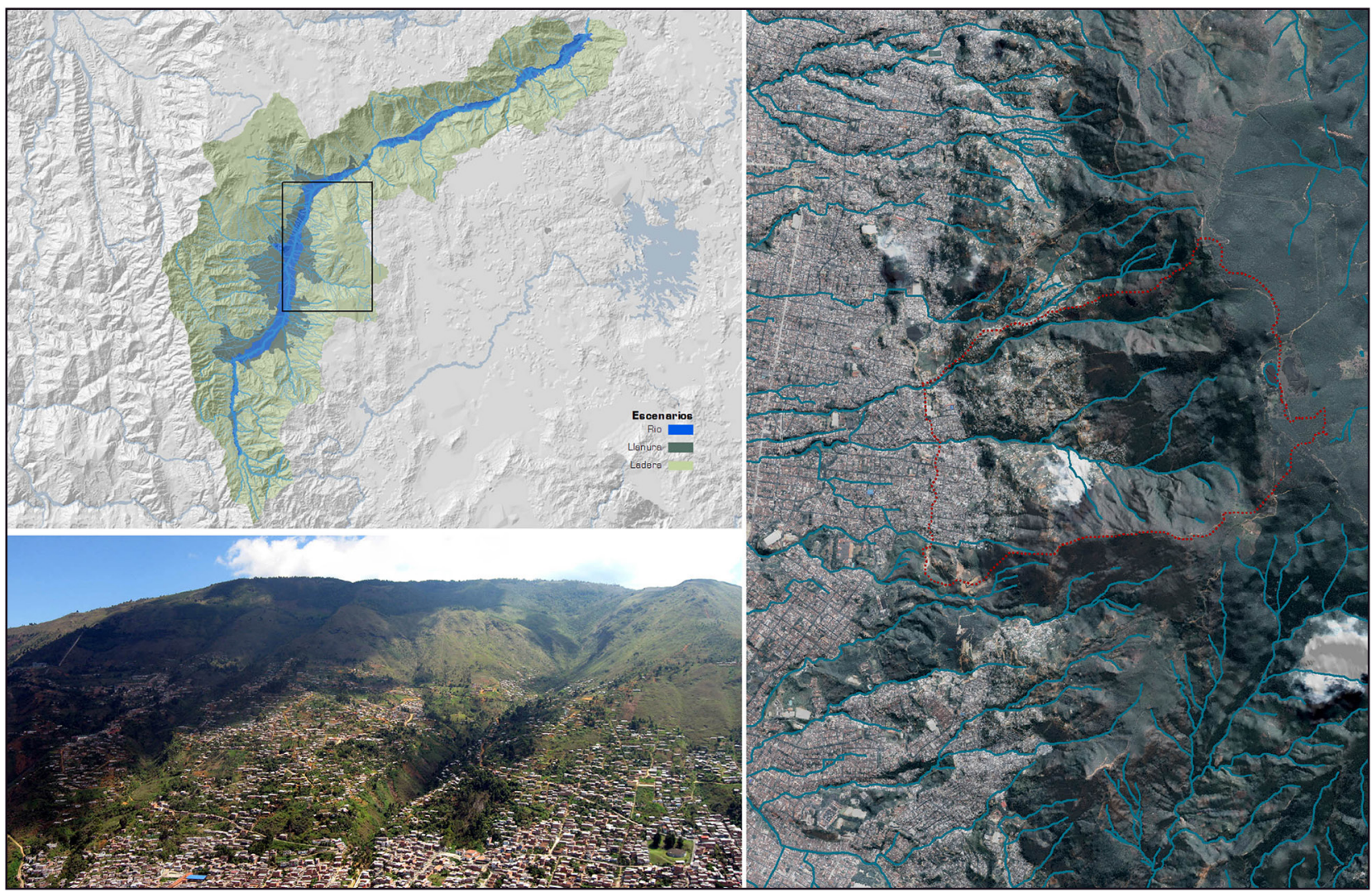

Figure 4 - The Aburra valley can be read through its major topographical structuring elements, the river, slopes, and area of steep ravines in between. The study area for the second phase of research, La Honda and La Cruz, is outlined here in red Source: Echeverri et al. (2013).

\section{Looking at the problem closely: La Honda and La Cruz}

To answer these and other questions, the teams from Urbam and Leibniz University, with financial support from the city government, initiated a second phase of research. In this phase, the goal was to look closely at specific communities in terms of local territorial and social dynamics in order to define and develop specific strategies to address non-formal settlement growth in unsafe areas by offering more sustainable alternatives to current practices of relocation from a social, environmental, and economic perspective. The research aimed to specifically identify solutions that would be advantageous not only to the communities being investigated, but within similar urban and environmental contexts elsewhere. For this second phase of research, the team chose two neighborhoods on the eastern ladera at particularly high risk-La Honda and La Cruz (Figures 4, 5 and 6). La Honda was a fast growing non-formal settlement just outside of the official urban growth boundary, and there were plans to remove much of the recent construction, even where the risk had not been assessed. La Cruz, on the other hand, was a long-established community just within the growth boundary, but which had experienced a destructive landslide in 2007 that claimed seven lives (Figure 7). After this event, the city began to devise a resettlement strategy for the neighborhood, which was accelerated after the 2010 catastrophe in La Gabriela. In 2011 the city published a regularization plan for the two neighborhoods, which called for the removal of 1300 houses, approximately half of the community's current population. Areas where people would be allowed to stay would still require significant engineering works to make the level of risk manageable. Construction started within La Cruz on three eight story high-rise apartment houses on vacant parcels that were deemed safe, to house 245 families from the neighborhoods (EDU, 2011).

Despite this well-intentioned effort, problems were immediately evident. Notwithstanding the 2007 landslide, the risk maps, and the urban growth boundary, nearly 500 new dwellings had been constructed in 


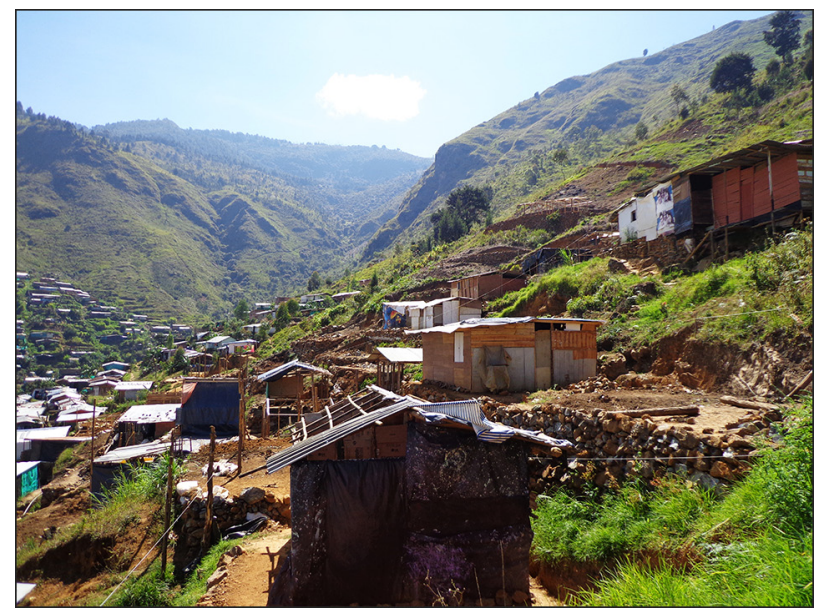

Figure 5 - New construction in La Honda, September 2012 Source: Echeverri et al. (2013).

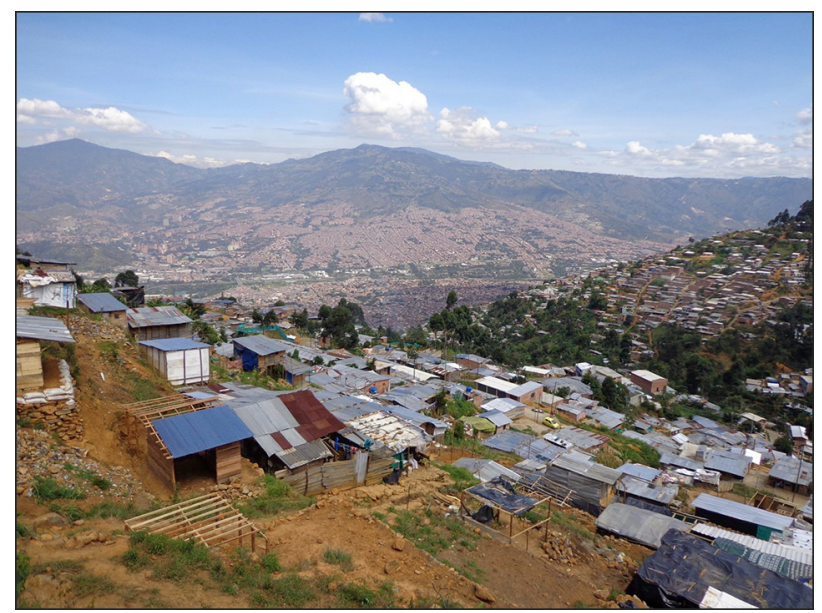

Figure $\mathbf{6}$ - View from Barrio La Honda (foreground) towards Barrio La Cruz (middle ground) and to the Aburra valley beyond, September 2012 Source: Echeverri et al. (2013).

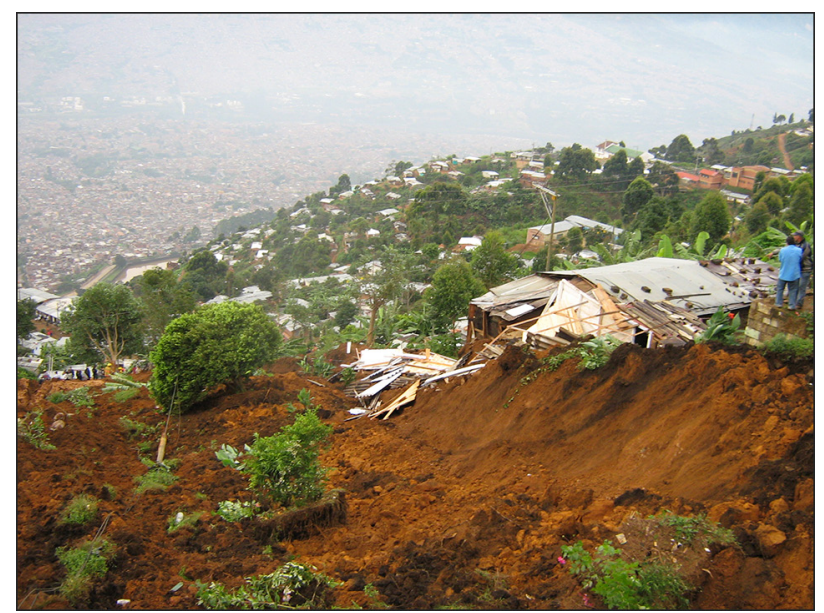

Figure 7 - Aftermath of landslide in Barrio La Cruz, 2007 Source: Departamento Administrativo de Pleneación Medellín (2007). the two neighborhoods between 2007 and 2012 and more were being constructed every day. Interviews with those in the community suggested that some were attracted to the neighborhood precisely because the area had been designated for resettlement. While many of the community's long-term residents dreaded the prospect of moving to the tall towers - others in the metropolitan area, the prospect of building a quick house in an unsafe zone, only to be resettled into a relatively high quality apartment within a few years, had become an attractor for growth (Echeverri et al., 2012, p. 84-87). A second incentive was the new high profile Cinturón Verde project being promoted by the local administration. This project was being sold as a solution to control growth on the high slopes, partly through urban consolidation strategies in the upper parts of the ladera, and partly through elements of ecological restoration and tourism, but it also included as a major component, the new infrastructural ring consisting of a transit monorail linking the outlying the ladera communities together. The research in Shifting Ground had already identified the presence of transit infrastructure as a major incentive for occupation, and just as land speculation happens in the formal sector, it seemed to be happening in the non-formal sector as well. For the research team, it seemed clear that these neighborhoods needed an alternative approach.

Several other trends in the neighborhoods pointed to the merits of seeking new approaches. Compared with other parts of the city, the two neighborhoods had a relatively high level of social stability, with low levels of crime and violence, and with several flourishing community organizations. Many long-term residents felt safe in their homes despite the geological risk. They had escaped war and violence, either in the countryside or in other parts of the city, and the threat of their homes being swallowed up in a landslide seemed either too abstract, too unreal, or a risk they were prepared to live with and manage. Following meetings and interviews with many in the community, the team's interest in developing a highly participatory approach in the context of the ladera was reconfirmed, recognizing that apart from the definition of an innovative planning approach, a key factor for success would be the community involvement, both in the definition of the strategies, and in the implementation process. 


\section{Developing a landscape and community-based approach}

The Urbam and Leibniz team started the research into the two communities with a fairly well developed spatial dataset provided by the city. This dataset, however, presented a static portrait of the communities at a certain moment in time, and it was lacking a more thorough understanding of the dynamic processes in the territory and in the community. To understand these dynamics, the team analyzed six sets of historical aerial imagery between 1959 and 2012, and supplemented this research with data from the city as well as interviews with long-term residents to understand the land ownership and property transfer dynamics (Figure 8). The team visited the site at frequent intervals, noting physical changes in the neighborhoods, but also conducting interviews with those who knew the community best. The team also participated of numerous meetings with community groups. Through these meetings and non-formal interviews, the team began to understand the community organization, functioning initiatives, and hopes and desires of those living in La Honda and
La Cruz. The team shared ideas concerning possible future scenarios and strategies for the community, and looked for successful case studies both regionally and globally investigating how such strategies have been successfully implemented in other contexts. The core teams' research was at every step supplemented with additional expertise provided by outside consultants in geology, ecology, and sociology. The results of this research were published in late 2013 in the report Rehabitar la montaña.

Over the course of the research, the Rehabitar team became especially interested in potential strategies falling into two general categories (Figure 9). The first group of strategies would be intended to mitigate the existing risk. While the underlying geology could never allow for a complete elimination of landslide threat on the ladera, simple measures like better management of stormwater could significantly reduce landslide triggers, while coordinated monitoring of conditions could allow for safe evacuation before the disasters happen. The second group of strategies would anticipate future risk, recognizing the likelihood that 70,000 people will non-formally occupy unsafe sites in the Aburra valley within the next twenty years unless preventative

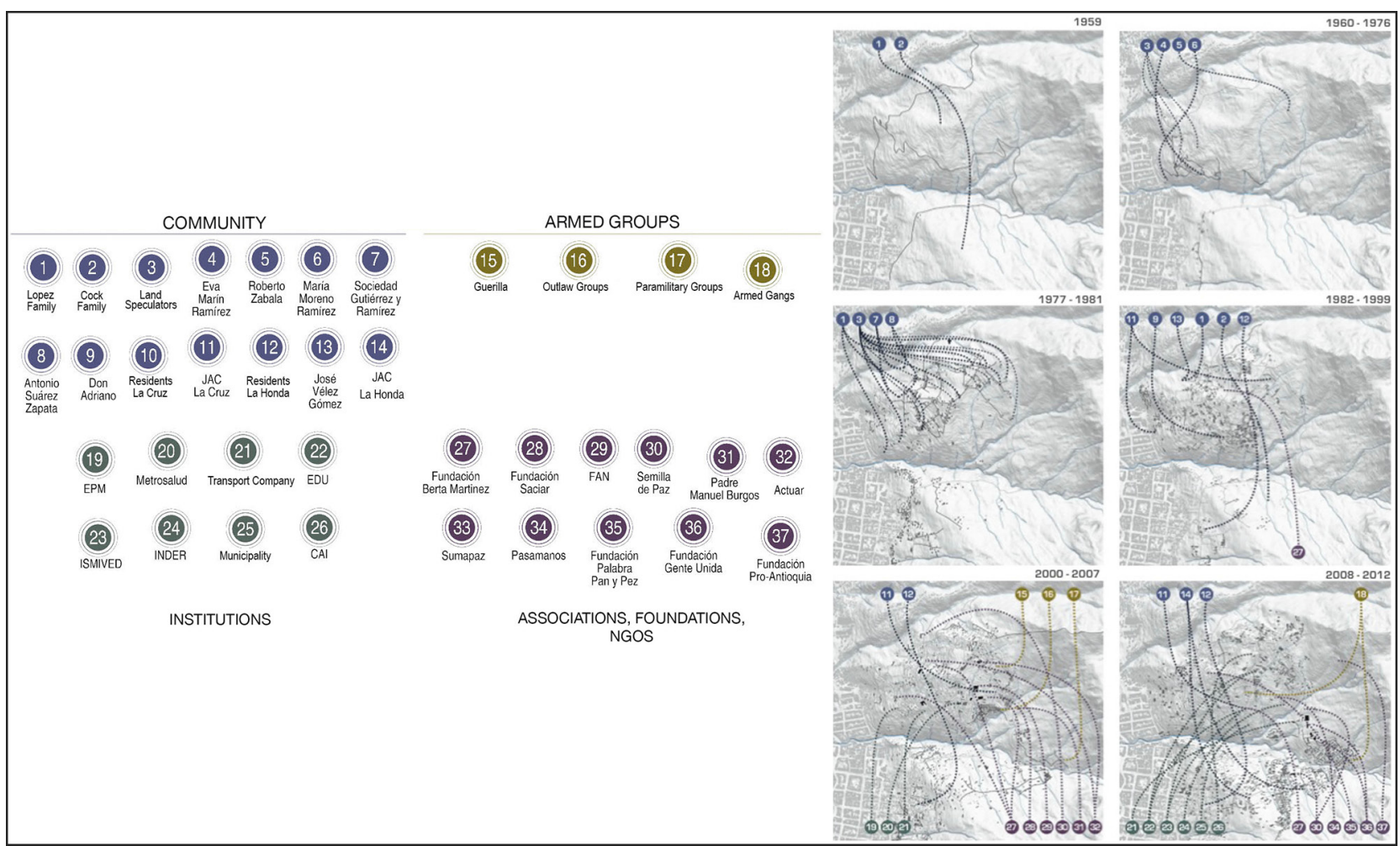

Figure 8 - Historical growth and actors in the study area, 1959-2012 Source: Echeverri et al. (2013). 
measures are taken. This could be achieved through a combination of providing beneficial, productive, and sustainable uses to unsafe sites in their un-built state, and by providing more attractive alternative sites for construction in areas that are determined to be safe. The team was especially interested in approaches that were community-based and "soft", recognizing that in many instances, traditional or "hard" engineering approaches would be required as well. It seemed clear, however, that a relatively small early investment by the city, to manage growth and prevent occupation of dangerous sites today, could obviate the need for expensive and unrealistic resettlement programs in the future. It was also clear that unless existing communities and those affected bought into the approach, it could create a high level of resentment, and any approach would probably be doomed to failure.

Under the umbrella of anticipation and mitigation approaches, the research identified a number of landscape-based strategies that could work together to manage risk and improve the residents lives. The team considered that in order to be effective, the strategies should be low-cost, relatively easy to implement without extensive technical expertise, scalable and applicable to similar sites elsewhere, and perhaps

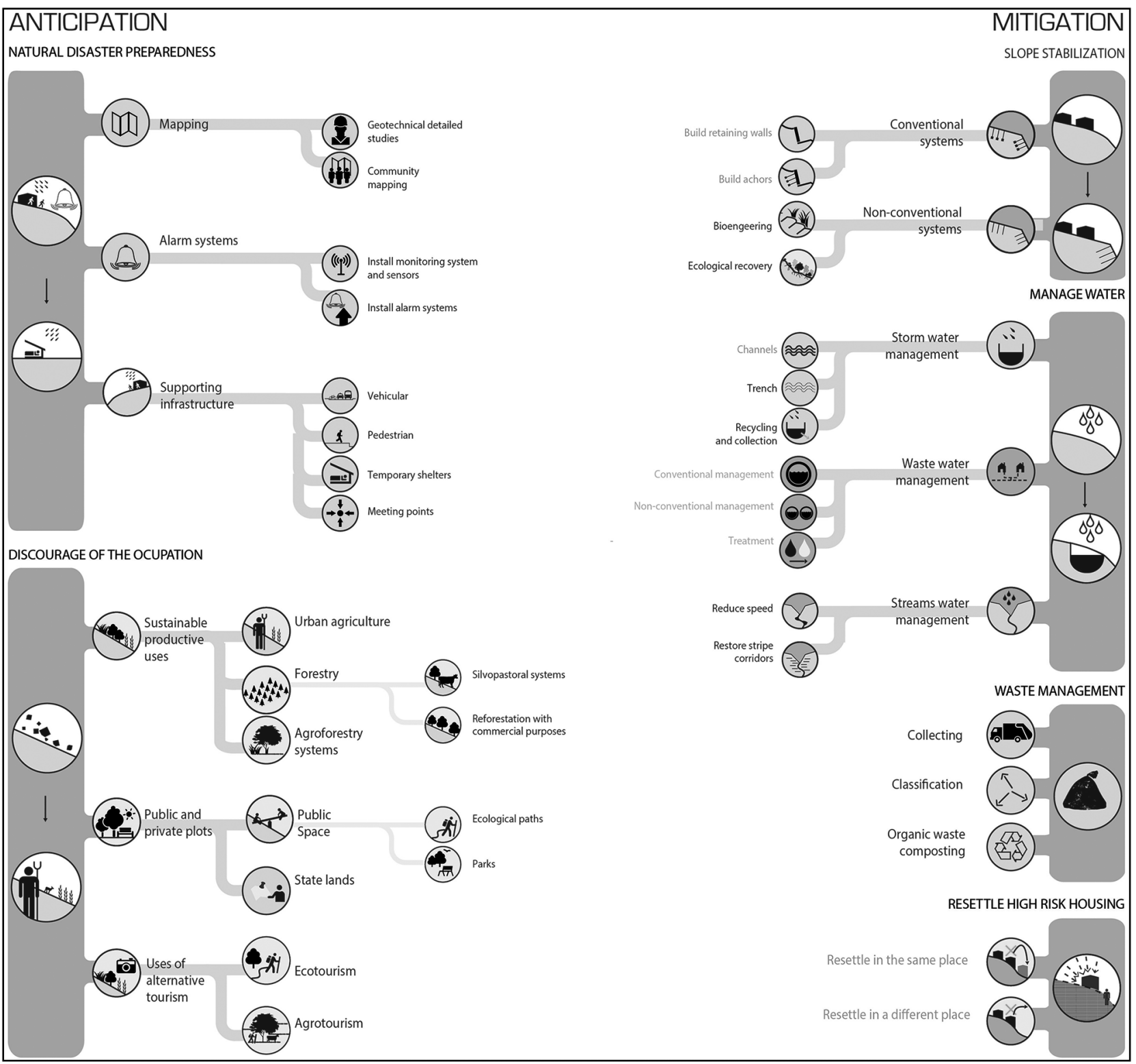

Figure 9 - Anticipation and mitigation strategies families that could be applied in the two settlements Source: Echeverri et al. (2013). 
most importantly, should offer clear benefit to those in the community, which often translates into a financial benefit. A final consideration was whether the strategy could benefit the metropolitan community as a whole, such as by providing ecological benefits or by working towards greater civic integration. One of the great successes of Medellin's Metrocable project was that it ended the isolation of periphery communities not only by providing more direct transit access to the city, but by bringing people from other parts of the city into their neighborhoods. An approach that works towards integration rather than drawing a red line on the map which could put an end to the residents' perception that the city has turned its back on them.

\section{Testing the strategies - pilot project proposals}

While the research team felt they had discovered many promising avenues for addressing the risk issues on Medellin's periphery, a number of questions remained unanswered regarding the strategies technical and social implementation. In order to bring the results from the second phase together, and to set the stage for a third phase of research, the team concluded the Rehabitar report by proposing five potential pilot projects that could be developed and implemented to test feasibility and to develop a implementation process (Figure 10, Table 1). Each of the drafts for the proposed pilot projects sought to bring together compatible sets of strategies, and also identify actions and actors over the short, medium, and long-term. These processes and actors were identified and refined through close consultation with outside consultants and community groups, especially with a trained sociologist and with a community-based organization called Sumapaz. In most cases, the actors identified were associated with already existing community groups, as well as government and non-governmental agencies. The team's intention was to develop and extend, where possible, already existing capacities and institutions.

While experts, governmental, and non-governmental organizations would inevitably play an important role, an important commonality among the projects proposed was the centrality of community based

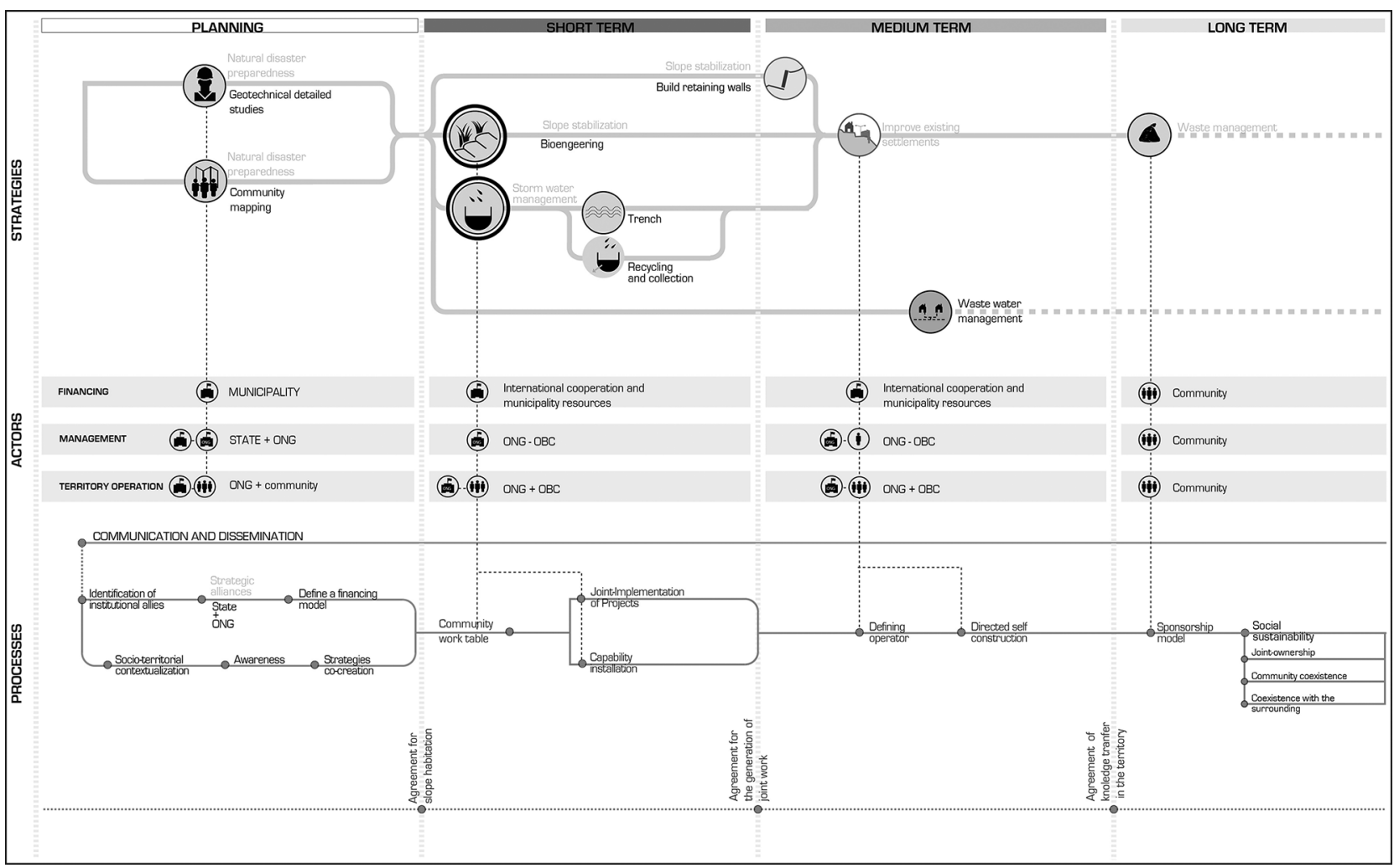

Figure 10 - Schematic process drawing of Pilot Project 2 (Mitigate Risk through Improved Drainage), showing strategies, actions, and actors in the short-, medium-; and long-term Source: Echeverri et al. (2013). 
Table 1. font and titles can be adjusted to match publication.

\begin{tabular}{|c|c|c|}
\hline Pilot & Goals & Key Strategies \\
\hline $\begin{array}{l}\text { Early Warning and } \\
\text { Evacuation System }\end{array}$ & $\begin{array}{l}\text { Provide early warning to residents } \\
\text { of landslide threats and evacuate } \\
\text { residents to safer sites }\end{array}$ & $\begin{array}{l}\text { - Slope monitoring } \\
\text { - Communication networks } \\
\text { - Identify safe refuges } \\
\text { - Improve evacuation routes }\end{array}$ \\
\hline $\begin{array}{l}\text { Mitigate Risk in } \\
\text { Existing Sites }\end{array}$ & $\begin{array}{l}\text { Manage water flows to prevent } \\
\text { soil saturation in order to reduce } \\
\text { likelihood of landslides }\end{array}$ & $\begin{array}{l}\text { - Community-based mapping } \\
\text { - Community-managed stormwater } \\
\text { networks } \\
\text { - Bio-engineered slope and stream } \\
\text { stabilization }\end{array}$ \\
\hline $\begin{array}{l}\text { Micro-farming on } \\
\text { High-risk Sites }\end{array}$ & $\begin{array}{l}\text { Establish productive land uses on } \\
\text { unsafe sites to reduce incentive for } \\
\text { non-formal occupation }\end{array}$ & $\begin{array}{l}\text { - Community farming collectives } \\
\text { - Composting program } \\
\text { - Bio-engineered terracing and } \\
\text { slope stabilization }\end{array}$ \\
\hline $\begin{array}{l}\text { Ecological Restoration } \\
\text { in High-risk areas }\end{array}$ & $\begin{array}{l}\text { Establish ecologically productive } \\
\text { zones to reduce incentive for non- } \\
\text {-formal occupation and to increase } \\
\text { overall slope stability }\end{array}$ & $\begin{array}{l}\text { - Community based forestry } \\
\text { - Bio-engineered slope and stream } \\
\text { stabilization }\end{array}$ \\
\hline $\begin{array}{l}\text { Sites and Services } \\
\text { Approach }\end{array}$ & $\begin{array}{l}\text { Provide basic infrastructure on } \\
\text { safe sites to encourage non-formal } \\
\text { occupation in low risk areas and to } \\
\text { reduce growth pressures on unsafe } \\
\text { sites. }\end{array}$ & $\begin{array}{l}\text { - Infrastructure for safe sites } \\
\text { - Security of Tenure agreements }\end{array}$ \\
\hline
\end{tabular}

organizations. Given the low level of daily governance assumed by civic authorities within these areas, the research team felt that the only way to succeed with an implementation strategy over the long term and to foster effective control over future land management and occupation issues was by ensuring that the local actors were the prime stakeholders. Through education on risk issues and adequate technical training, the team felt the communities could move towards effective self-management of their own territory, where civic authorities, NGOs and other strategic actors became secondary facilitators and supporters of the broader initiatives.

What follows is a short description of some of the goals, strategies, and actors associated with each of the five proposed projects, as well as relevant case studies that were used to inform their development.
Pilot 1 - Monitoring risk and developing an evacuation infrastructure

An important component in mitigating the impact of disaster is the foreknowledge that a disaster is imminent or likely. Even if over the long-term, removal of residents in the high-risk zones of the ladera becomes necessary, this process would require significant amounts of monetary resources and time, and in the interim, people would go about their lives in the shadow of uncertainty. On this basis, the team recommended that one of the first interventions in the communities at risk should be the development of a comprehensive monitoring system, as well as a community-based network of shelters and evacuation routes.

Recent advances in remote sensing, GPS technology, and data-collection, have been changing the way cities are managed around the world. Sensors that can monitor landslide risk factors such as rainfall, soil 
saturation, and earth movement could be installed at relatively low cost in high- and medium-risk sites along the ladera. The success of such program depend on coordinated organizational oversight of the technical and scientific aspects of monitoring, a community-based organization capable of responding when certain warning thresholds are met, and perhaps most importantly, a clear channel of communication between the two. In the case of Medellin, these core capacities already exist. The organization SIATA (Sistema de Alerta Temprana), funded by a public and private partnership, currently monitors warning signs linked to 71 sensors across the valley. These sensors monitor precipitation, wind speed, water amounts in the quebradas, as well as slope movement. While the intent is to provide warnings for the whole community, in reality, at the present time, most sensors are linked to monitoring conditions around key infrastructure; the only sensor on the eastern ladera at this time is one which measures earth movement near a key water supply pipe (SIATA, 2013). Expanding this network with a commitment to monitoring conditions in precarious communities could be a first step to saving lives.

At this time, the neighborhoods also have the basis for an organization that could respond to warning signs and imminent disasters. The Guardia Civil is an organization of 500 community volunteers in La Cruz with this purpose only. They have responded to small disasters in the past-at least a couple of houses collapse in each of the two yearly rainy periods-and were on hand during the 2007 landslide. Unfortunately, when the team interviewed the head of this organization, she was unaware that the monitoring program existed, or how a warning would be sent out. This problem could also be solved with education and regular communication between the parties. Therefore, a primary goal of the first pilot project would be to simply build and extend existing capacity.

As a second step, an improved evacuation infrastructure, based on a system of improved walkways and designated shelters, would make residents more likely to leave their homes for safety in the event of a warning. The creation of designated routes for the worse case scenario, such as heavy rains, would also be the basis of improved pedestrian accessibility in the daily lives of those living on the steep slopes. In addition to more traditional emergency shelter systems associated with public buildings such as schools and churches, a systematic shelter system with easy to reach and dispersed refuge points could be developed by improving the homes of volunteers in safer sites with small subsidies in exchange for providing temporary shelter to evacuated neighbors (Hayashi et al., 2010).

\section{Pilot 2 - Mitigating risk through improved drainage}

Landslide fatalities can occur only when three conditions are met; the first two, relief and habitation, are self-evident; the third condition is a landslide trigger. This trigger is almost always associated with soil saturation, most often following a period of heavy rain, as soil saturation can dramatically lower the coefficient of friction in a mass of earth (Petley, 2012). As the research in Shifting Ground suggested, this natural process can be accelerated when human constructions alter existing drainage patterns. At the same time, human interventions can also reduce the risk of soil saturation with efficient, well-maintained, and unclogged drainage systems, which can go a long way towards mitigating the risk. Therefore, the second pilot project proposed implementing such strategies in communities facing significant (but not severe) geological restrictions, where good management practices could be shown to reduce potential risk.

The complexities associated with effective stormwater management are rarely evident at a broad planning scale; it is necessary to look closely at the site. These site conditions, however, can change over time, and drainage patterns and problems might not be evident except during periods of inclement weather. In addition, an effective stormwater design that currently works might not work in the future, such as when a new house is built, or when a drain is clogged with trash or plant debris. For this reason, the only effective approach, especially in the dynamic context of non-formal settlements, would be a community-based one. Educating community members as to risk factors, making them aware of the consequences of poor drainage, and providing incentives for them to participate in the implementation and maintenance, is the first stage to implementing better drainage system (Figures 11 and 12) (Holcombe \& Anderson, 2013). The educating and mapping process could also lead to better building practices in the future and a more careful monitoring of the 
condition of the land. Community members could also be paid to monitor and maintain drainage ways, removing debris at regular intervals. When drainage ways are integrated sensitively into public space, an additional incentive to maintain and protect them could be provided.

\section{Pilot 3 -Micro-farming on Steep Slopes}

Unoccupied sites close to existing non-formal settlements face a high risk of occupation in the future, unless an interested landowner with clear incentive to keep the plot free from settlement regular monitors the site. Reoccupation of sites can even occur after a resettlement program removes people from a piece of land. As such, strategies need to be developed to vacant sites in areas of significant risk more attractive in an un-built state to forestall possible occupation. These sites should have a clear land use that will not increase slope instability. In recent years, a much touted strategy for vacant land in urban and peri-urban areas has been to dedicate such land to agricultural production. This is one possible land use that could be explored in the third pilot project (Figures 13 and 14). For such a scheme to work in the context of Medellin's eastern ladera, technical challenges of farming on steep slopes and concerns on the soil low fertility would need to be addressed. Evident successes in nearby areas, however, demonstrate that this could be a viable strategy. A few kilometers to the south of La Honda and La Cruz, on the hill Pan de Azucar, a small collective established a self-organized micro-farming project on a high-risk piece of land near the spot where Medellin's worst disaster occurred, the 1985 Vilatina landslide which killed around 500 people. In this steep site, the group had used collected plant material to build micro-terraces into the hillside, and was successful in raising a wide variety of

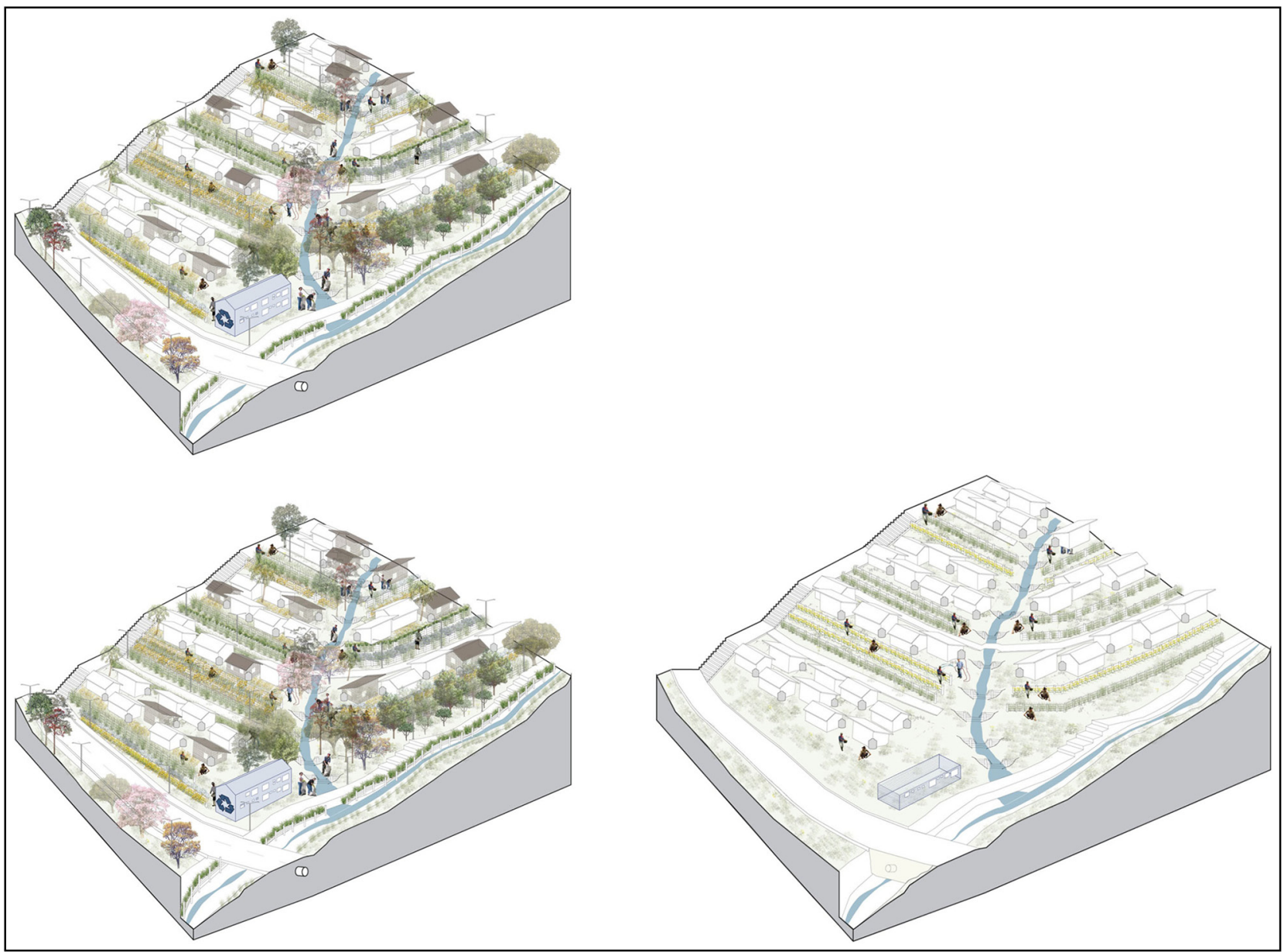

Figure 11 - Isometric showing short, medium-, and long-term actions for Pilot Project 2 spatially

Source: Echeverri et al. (2013). 
plants despite the soil conditions. The farmers had a clear interest in the piece of land, but since the project was run collectively, when one farmer no longer had interest in the project, for example if a more lucrative

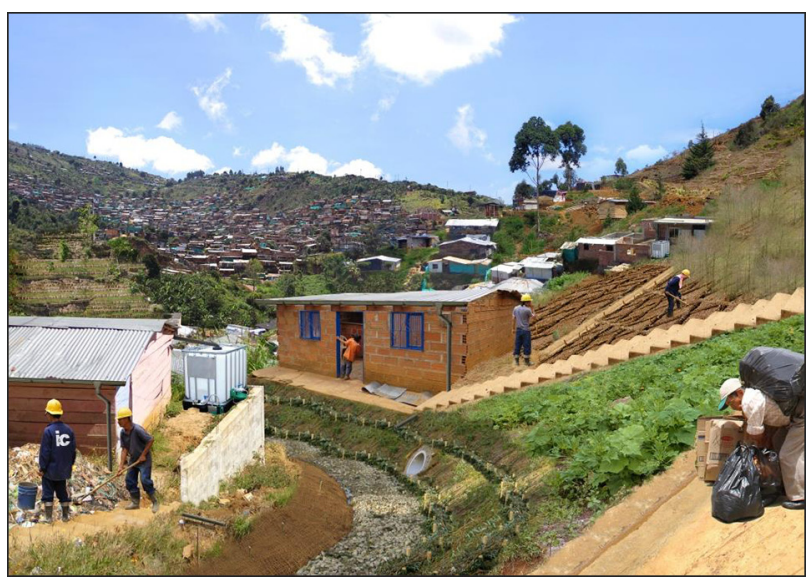

Figure 12 - Photo collage showing implementation of Pilot Project 2 in the community Source: Echeverri et al. (2013). opportunity arose, they could easily step out of the project and others could take their place. A similar, but more formal community based organization could be formed in La Honda and La Cruz to manage the use of designated micro-farming sites, with a clear charter and tenure over the land. In the mid- and long- term the implementation of local food markets, as well as eco-touristic programs could add potential social and economic benefits to the micro-farming initiative.

\section{Pilot 4 - (Re) establishing Ecology}

For sites that are currently unoccupied, and which are somewhat removed from existing settlement, the team proposed an active program of river corridor and slope afforestation (Figure 15). Community based forestation projects have proved successful in other non-formal contexts, where residents involved

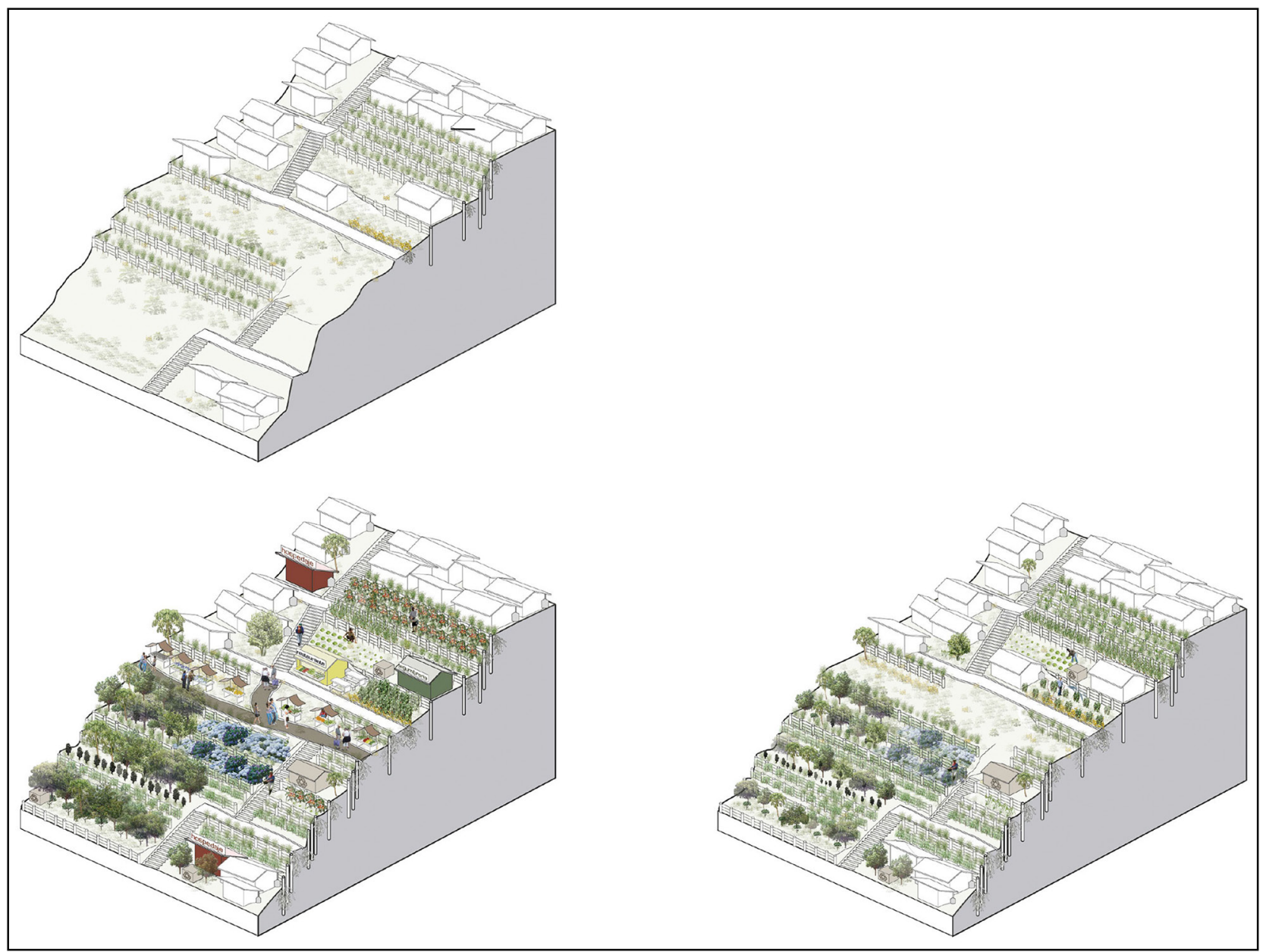

Figure 13 - Isometric of short-, medium-, and long-term actions in the micro-farming pilot project Source: Echeverri et al. (2013). 
in the planting and maintenance of designated protected areas become vigilant stewards of the land. (The Municipal Secretariat of Social Development, Rio de Janeiro, 1994) The Rehabitar team identified an already existing organization within the study area,

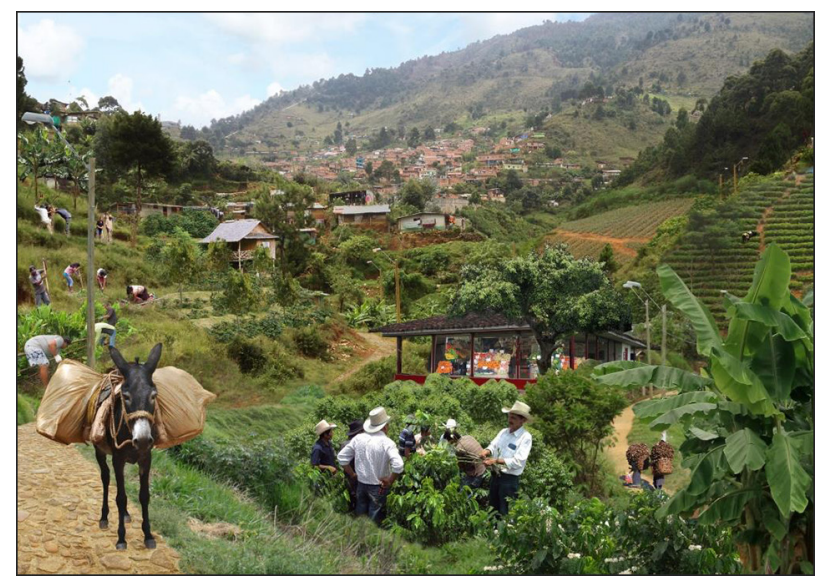

Figure 14 - Photo collage of micro-farming pilot project Source: Echeverri et al. (2013). with desire and inclination to engage in forestation and ecological restoration projects. The group Mas bosques (more forests) held weekly meetings and was pursuing projects to restore the native dry forest community. The willingness of the community to help establish and maintain the growing forest could be supplemented with experts who have developed simple, yet effective, bio-engineering techniques and slope stabilization. One such group, CIPAV, has successfully implemented numerous bio-slope stabilization and landslide prevention projects in other parts of Colombia, usually in rural contexts (CIPAV, 2011). The technique is promising, and could be adapted to a peri-urban setting such as the ladera. With technical advice and guided by trained ecologists, the right species mix appropriate for the slopes of the ladera could be selected and nurtured.

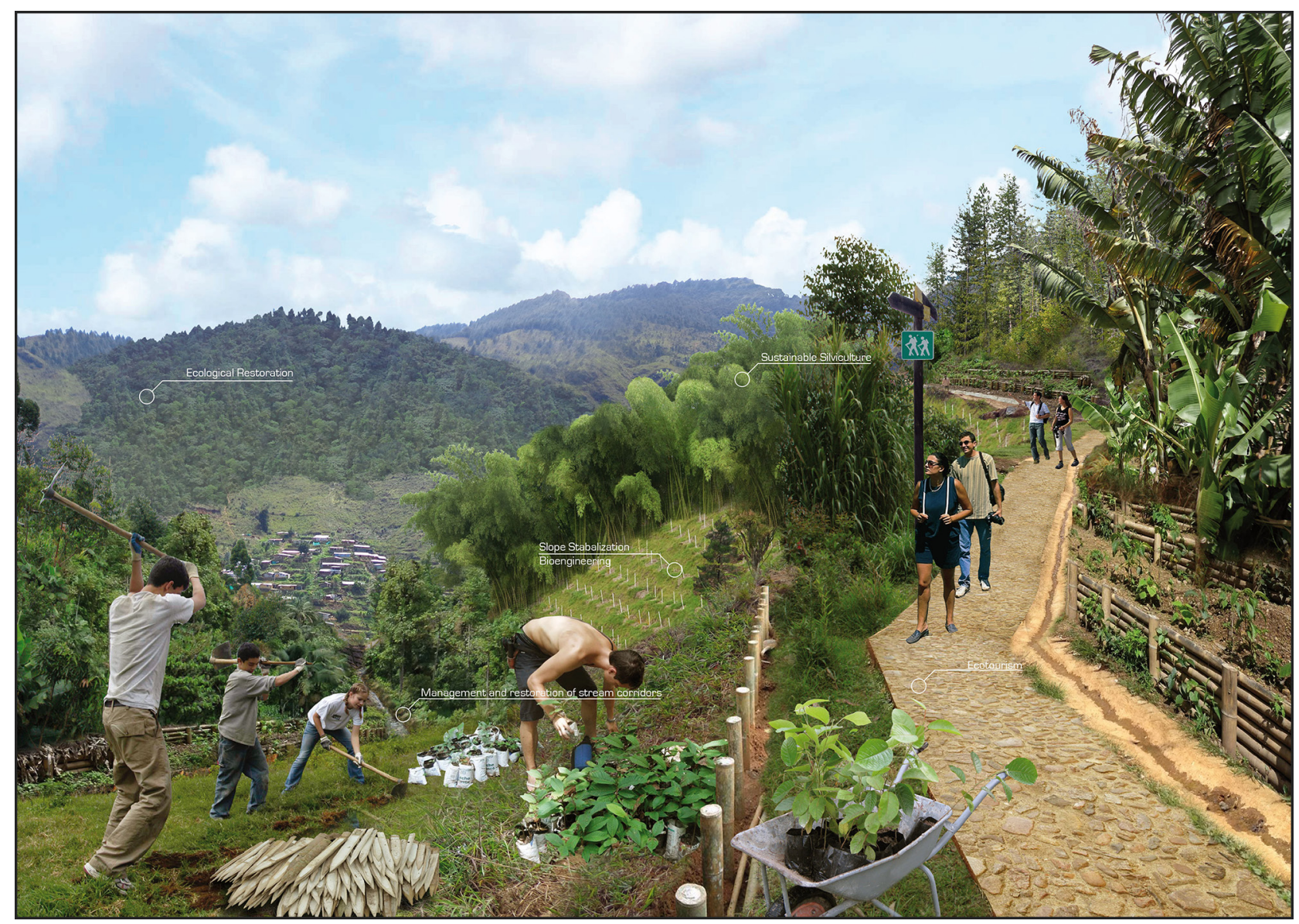

Figure 15 - Photo collage of forestation and ecological restoration pilot project Source: Echeverri et al. (2013). 
Pilot 5 - Addressing future growth - the "Sites and Services" approach

The last pilot project addressed the reality that some of the families settled in unsafe areas would eventually need to be relocated, and new residents from either immigration or natural increase would need to find a home somewhere. Generally, that is how the non-formal housing issue is addressed, as a housing problem, resulting in the construction of social housing by the public sector. Often, however, issues in non-formal communities have small connections with the quality of self-built housing, which is often quite safe, but with the physical and legal characteristics of the land upon which the houses are built, and with the infrastructure that services them. Since government resources in the majority of the developing world can be quite limited, they should generally not be applied to the construction of actual dwellings, but in identifying safe sites, arranging security of land tenure, and in the provision of basic services. All of this can be done in a more cost effective manner before non-formal occupation actually happens. This is nota new idea; a number of so-called "sites and services" approaches were developed in the 1970s but fell out of fashion as interest moved forward. Continuing research by Prof. Reinhard Goethert at MIT, where he evaluates the successes of past sites and services projects shows that this approach should be revisited, but that the community involvement is crucial to the project (Wakely \& Riley, 2010). In the specific cases of La Honda and La Cruz, the team suggested that the community could be organized through a cooperative model known in Medellin as OPV (Organizaciones Populares de Vivienda), a non-profit organization aiming to develop social housing for its members through self-help programs. The OPV would lead the building process, and eventually would operate and maintain the new housing developments. Services and public infrastructure would be provided by the local public administration while land tenure would be transferred to the OPV in perpetuity.

\section{Next steps}

The pilot projects were designed so that one, some, or all could be further developed and implemented in order to make recommendations for broader implementation. The implementation of pilot projects would allow the team to clarify many unanswered questions that arose over the course of the first two phases of the research. Some of these questions were of technical nature. How effective and how sensitive are the monitoring systems? What monitoring systems work best in this context? What plant species will grow in the unique soil conditions on the eastern slopes of the valley? More importantly, however, the pilot projects are intended to develop a social process to implementation, while at the same time educating existing residents to aspects of risk. Presentations to the community of the first phases of research have been mostly positive, and potential actors for each of the five pilot projects have already been identified.

While hoping to receive more answers by implementing and subsequently monitoring the five pilot projects, the current research has already yielded valuable results. It shed light on the historical process of non-formal urbanization in Medellin and its primary relation to urban growth boundaries and basic infrastructure while the steepness of the slopes played a secondary role in shaping the direction of development. It also clears the necessity to find an alternate path to current approaches of large-scale removal and resettlement of communities in high-risk zones or in areas outside legal growth boundaries. The graphic projection of an alternate path through soft strategies deducted from existing reference projects throughout the world, allowed the team to convey its ideas to the public, especially to the residents, NGOs, and government officials. This ongoing discussion will further specify the proposals and their experimental implementation through real-life interventions limited in scale. The research showed that there are many in the communities affected who would voluntarily offer their time and skills, but with modest additional public funding, many more would become involved and stay committed to the project's goals.

As the team moves into the next phases and the pilot projects are implemented, it is almost certain that there will be surprises and modifications during implementation in a process where the residents are seen as the central actors. Another key obstacle that should be overcome, however, is political. Fajardo's interventions undoubtedly improved many lives in Medellin, and the most important ones were largely invisible, but the most visible and talked about were magazine cover ready and something that could easily be pointed out as a tangible political accomplishment. In contrast, and although funding demands may be 
modest, long-term projects that involve complex community involvement processes may take years to show demonstrable results and the risk of failure is high should any of the actors loose interest in the project. As such, an important consideration that needs to be addressed is how such soft strategies could achieve success while maintaining visibility and political backing, or how such approaches could be better integrated into a larger narrative for the city as a whole. The team is seeking to embrace this intricate process and intends to document the process clearly, while remaining embedded as an actor itself. Ultimately, it will take years, persistence, and patience to yield empirical results related to the proposed actions. Such approaches, however, will become increasingly necessary in the rapidly growing developing world where resources are often scarce and where managing disaster risk becomes an increasingly pressing concern. The development and successful implementation of strategies in the context of Medellin could once again serve as a leading example for implementation in similar contexts around the world.

\section{References}

Departamento Administrativo de Planeación Medellin. (2007). Landslide in El Barrio La Cruz. Medellin. (Photograph).

Echeverri, A., Werthmann, C., \& Vélez Villa, A. (Eds.). (2012). Shifting Ground: precarious settlements and geological hazard in Medellín. Medellín: EAFIT University/ Harvard University.

Echeverri, A., Werthmann, C., \& Orsini, F. (Eds.). (2013). Rehabitar la montaña: estrategias y procesos para un habitat sostenible en las laderas de Medellín. Medellín: EAFIT University.

Empresa de Desarollo Urbano - EDU. (2011). Proyecto de regularización y legalización urbanística del barrio la Cruz y el sector la Honda. Medellin: Municipality of Medellin.

Fajardo, S. (2007). Medellin, del miedo a la esperanza (Conferencia en el TEC de Monterrey, Mexico). Retrieved in XX June 2015, from https://www.youtube.com/ watch?v=mlKz1GSsXpQ

Fundación Centro para la Investigación en Sistemas Sostenibles de Producción Agropecuaria Vieillesse - CIPAV. (2011). Convenio 46/3545 ISAGEN-CIPAV. Resturación ecológica en la cuenca del rio Amoya. Chaparral, Tolima. Cali: CIPAV.
Hayashi, H., Hasegawa, S., Nonomura, A., \& Sato, T. (2010). Selection safe places for temporary shelter from debris flow and landslide disasters in mountainous area. In: Proceedings of the Society for Social Management Systems Symposium. Kochi: Society for Social Management Systems.

Holcombe, E., \& Anderson, M. (2013). Community-based Landslide risk reduction: managing disasters in small steps. Washington: World Bank.

Municipality of Medellin. (1985). Plan de desarrollo metropolitano del Valle de Aburra: para la consolidación de la metrópoli. Medellin: Municipality of Medellin.

Municipality of Medellin. (2011). BIO 2030 plan director Medellín, Valle de Aburrá (1st ed.). Medellin: Municipality of Medellin.

Ojeda, J., \& Donnelly, L. (2006). Landslides in Colombia and their impact on towns and cities. In Proceedings of the 10th Engineering Geology for Tomorrow's Cities (Paper 112, p. 10-12). London: The Geographical Society of London.

Petley, D. (2012). Global patterns of loss of life from landslides. Geology, 40(10), 927-930. http://dx.doi. org/10.1130/G33217.1

Salazar, B. P. (2011). Programa de Mejoramiento Integral de Barrios - PMIB - caso Juan Bobo. In MesaEditores. Laboratorio Medellín: catálogo de diez prácticas vivas (1st ed., p. 84-97). Medellin: Alcaldía de Medellín.

Schnitter, P. (1999). Pilot plan proposal for Medellín by Wiener and Sert: CIAM's theory of urban plannin - its transfer to practice. Proceedings of the ACSA International Conference (p. 217-221): Rome: ACSA.

Sistema de Alerta Temprana del valle de Aburrá - SIATA. (2013) Retrieved in 10 November 2013, from http:// siata.gov.co.

The Municipal Secretariat of Social Development, Rio de Janeiro. (1994). Paid self-help reforestation project: Rio de Janeiro (Urban Environment-Poverty Case Studies Series, MCP-018). Rio de Janeiro: Retrieved in 25 October 2014, from www.megacitiesproject.org/pdf/reforestation.pdf

Wakely, P., \& Riley, E. (2010). The case for incremental housing (CIVIS: Special Issue World Urban Forum, 5). Washington: Cities Alliance.

Received: June 15, 2014

Approved: Sept. 21, 2015 